\title{
Formation of heat-induced protein aggregates in milk as a means to recover the whey protein fraction in cheese manufacture, and potential of heat-treating milk at alkaline $\mathrm{pH}$ values in order to keep its rennet coagulation properties. A review
}

\author{
Fanny GUYOMARC'H*
}

UMR 1253, Science et Technologie du Lait et de l'Cuf, Inra-Agrocampus Rennes, 65 rue de Saint-Brieuc, 35042 Rennes Cedex, France

Received 10 June 2005 - Accepted 6 October 2005

\begin{abstract}
The heat-treatment of cheese milk, or whey, to denature the whey proteins has long been the most applied means of recovering these proteins, either directly in the cheese curd, or as added to the cheese milk prior to renneting. In heat-treated milk, the interaction of the denatured whey proteins with the casein micelles, however, limits the primary phase of the enzymatic reaction, and prevents fusion of the casein micelles. Cheeses containing heat-denatured whey proteins also exhibit excessive moisture, a crumbly and soft texture, and poor meltability. Various technological means to reduce these drawbacks are reviewed. Especially, it is generally accepted that the heat-treatment of skim milk at alkaline $\mathrm{pH}$ generates aggregates of denatured whey proteins and $\kappa$-casein in the serum phase of milk, rather than on the surface of the casein micelles. As a consequence, the casein micelles are depleted in $\kappa$-casein, and free of denatured whey proteins. However, the attempts made to exploit this interesting protein distribution in cheese-making remain scarce, despite their promising results.
\end{abstract}

rennet coagulation / heat-treatment / whey protein / cheese

摘要 - 在干酪生产过程中通过热处理回收乳清蛋白, 以及在碱性 $\mathrm{pH}$ 下加热牛乳以保持凝乳 酶的凝固特性（文献综述）。长期以来在干酪的生产过程中一直采用热处理牛乳或乳清使 乳清蛋白变性, 通过这种办法来回收这些蛋白质, 有时直接将这些蛋白加入凝块或在凝乳 之前将这些蛋白加入牛乳中。在牛奶的热处理过程中, 由于变性的乳清蛋白和酪蛋白胶束 之间相互作用限制了初期的酶反应, 进而阻止了酪蛋白胶束的融合 (聚合)。干酪中含有 变性的乳清蛋白会表现出水分含量过高、质地脆、软、熔融性非常差。关于如何克服甶酪 生产中这种缺陷的技术手段已有许多文献报道。通常比较容易接受的方法是在碱性条件下 热处理脱脂乳, 此时变性的乳清蛋白和 $\kappa^{-}$酪蛋白的凝聚物存在于牛乳的乳清相中, 不是在 酪蛋白胶束的表面。其结果是酪蛋白胶束中既不存在 $\kappa^{-}$酪蛋白也不含有变性的乳清蛋白。 尽管这种处理方法可以获得令人满意的结果, 但是对这种蛋白分布在干酪生产中的应用还 很少。

凝乳酶凝乳 / 热处理 / 乳清蛋白 / 干酪

* Corresponding author (通讯作者): fanny.guyomarch@ rennes.inra.fr 
Résumé - Récupération des protéines sériques du lait dans le caillé fromager au moyen de la formation d'agrégats thermo-induits, et intérêt de chauffer le lait à pH alcalin dans le but de conserver son aptitude à la coagulation présure. Revue. Le traitement thermique du lait ou de lactosérum est un des moyens les plus utilisés pour incorporer les protéines sériques ainsi dénaturées, soit directement dans le caillé, soit sous forme d'ingrédient ajouté au lait fromager. Cependant, l'interaction entre les protéines sériques dénaturées et les micelles de caséines, due au chauffage du lait, a pour effet de limiter la phase primaire de la coagulation par la présure, ainsi que la fusion des micelles déstabilisées. Les fromages obtenus à partir de lait chauffé sont aussi plus humides, plus mous, plus granuleux et moins aptes à la fonte que les fromages standards. Les moyens technologiques de pallier ces inconvénients sont rappelés. En particulier, il est connu que le traitement thermique du lait à $\mathrm{pH}$ alcalin favorise la formation d'agrégats de protéines sériques dénaturées et de caséine $\kappa$ dans la phase soluble du lait, plutôt qu'en surface des micelles de caséines. En conséquence, la teneur en caséine $\kappa$ des micelles est réduite et celles-ci ne sont pas recouvertes de protéines sériques dénaturées. Cependant, peu d'études ont tenté d'exploiter ces caractéristiques du lait chauffé à $\mathrm{pH}$ alcalin en technologie fromagère, malgré des résultats prometteurs.

coagulation présure / traitement thermique / protéine sérique / fromage

\section{INTRODUCTION}

In traditional cheese-making processes, a large proportion of the whey proteins $(\beta$-lactoglobulin, $\alpha$-lactalbumin, bovine serum albumin, immunoglobulins, lactoferrin, enzymes, etc.) are eliminated in the whey during drainage. These whey proteins have excellent nutritional value, due to their high content in cystein, and to the high content of $\alpha$-lactalbumin in tryptophan residues [91]. They also have very good foaming and emulsion properties in their native state, or when partially denatured [34, 79, 167], and high water retention and gelation properties in their denatured state $[32,33,79,155$, 160].

The recovery of the whey protein fraction in cheese technology has long been extensively investigated. Heat-treatment of the milk to denature the whey proteins and aggregate them with the casein fraction is one of the major means to reach this goal; however, this causes severe inhibition of gel formation, and texture defects of the curd $[75,87,142,168]$. The present review stresses that heat-treatment of skim milk at $\mathrm{pH}>6.7$ induces changes in the distribution of the heat-induced protein aggregates between the serum and the micelle phases of milk, related to the higher dissociation rate of $\kappa$-casein upon heating at alkaline $\mathrm{pH}$ values, and suggests that new technological approaches may be investigated in order to optimise the recovery of the whey proteins in the cheese curd, and improve the rennet coagulation properties of the heated milk.

\section{PRINCIPAL MEANS FOR THE RECOVERY OF THE WHEY PROTEIN FRACTION IN CHEESE-MAKING}

\subsection{Thermal coprecipitation of the whey proteins and casein}

Heat-treatment of milk at temperatures exceeding $\sim 60^{\circ} \mathrm{C}$ leads to denaturation (unfolding) of the whey proteins, followed by aggregation through hydrophobic interaction and disulphide-thiol interchanges to form heat-induced aggregates, either on the surface of the casein micelles (micellebound aggregates), or in the serum phase of the milk (serum aggregates) [3-5, 116]. These aggregates essentially contain whey proteins and $\kappa$-casein; micelle-bound aggregates may also contain traces of $\alpha_{\mathrm{s} 2}$-casein $[26,62,121,139,144]$. They can reach a diameter of 30 to $100 \mathrm{~nm}[76,157]$.

Serpelloni [136], Banks [10], Banks et al. [12] and Law et al. [86] have taken advantage of the heat-induced binding of denatured whey protein to the casein micelles to recover the whey proteins in Cheddar curds. Another application of this approach in cheese-making can be found in Sanchelima [130], where a continuous flow process is described. The heat-treatments used in these studies range from 80 to $95^{\circ} \mathrm{C}$ for a few seconds to several minutes, so that significant heat-denaturation of the whey proteins can be obtained [30, 31]. Ultrafiltration (UF) may be used to increase whey 
protein concentration, and hence increase the rate of whey protein denaturation during heating [122]. For fresh cheese, the socalled Thermo-Quark process can be applied, where the rennet coagulum of acidified, heated $\left(90-95^{\circ} \mathrm{C}, 2-3 \mathrm{~min}\right)$ skim milk is further heated at $50-60{ }^{\circ} \mathrm{C}$ for $1-2$ min to complete the denaturation of $\alpha$-lactalbumin prior to drainage by centrifugation [118].

\subsection{Addition of heat-denatured whey protein to cheese milk}

To avoid the consequences of the heatinduced interaction between denatured whey proteins and $\kappa$-casein on the rennet coagulation properties of the milk (see Sect. 3), the whey proteins may be recovered by heating the lactoserum itself, prior to addition to cheese milk [109]. During heating, the whey proteins denature and aggregate through hydrophobic interactions and thiol/disulphide exchanges. Increased protein concentration prior to heating allows increased denaturation rates $[66,68]$, e.g. using UF concentration of whey [21], as opposed to concentration of total dry matter using evaporation where increasing lactose content exerts a protective effect on the native structure of $\beta$-lactoglobulin [123, 124]. As opposed to the milk medium, where the reported sizes for heat-induced protein aggregates are $<1 \mu \mathrm{m}$, the whey proteins in heated lactoserum readily form large, visible flocs that can reach up to the $\mathrm{mm}$ scale. The heat-aggregated whey protein can then be easily concentrated by UF $[21,119]$ or centrifugation, e.g. by the Centri-Whey process $[52,53,161]$. The size of the aggregates can be controlled by physical means, including homogenisation [110] or shear of the heated whey [40], or the control of the whey protein denaturation through the temperature of heating [8,147]. At constant temperature, decreasing lactose concentration reduces the protective effect of the sugar on denaturation of the whey proteins $[21,124]$, while a combination of increased heating regimen and lactose concentration produces large aggregates with a sandy texture [70, 147]. Adjusting the $\mathrm{pH}$ of the whey, generally in the range 3.5 to 7 , prior to heat-treatment, is also a common method to control the size and hydration of the aggregates, although the reported optimum $\mathrm{pH}$ values differ significantly $[40,84$, 148]. Other chemical means used to control the size of the aggregates are the variation in concentration of calcium or sodium salts $[23,148]$, or the use of transglutaminase enzyme [145].

Commercial applications of microparticulated whey products have found outlets under trademarks such as Dairy-Lo ${ }^{\mathrm{TM}}$ (Pfizer Food Science Group, New York, NY, USA) or Simplesse ${ }^{\circledR}$ (NutraSweet Co., St Louis, MO, USA). These products are largely used as fat substitutes in the manufacture of low-fat products, including cheeses.

As an alternative to the use of commercial ingredients, the addition of particulated whey protein to cheese milk can also be performed in a single flow process. This involves the separation of the casein and whey protein fractions using membrane filtration techniques [126] and separate heating of the two fractions, followed by re-combination [105].

\subsection{Use of membrane technologies to pre-concentrate cheese milk}

As opposed to the above approaches, concentration of the total protein fraction of milk by UF allows the retention of native whey proteins into either intermediate concentrated retentates, or "pre-cheese" retentates which have essentially the composition of the targeted cheese [103, 112]. The precheese can be coagulated using acidification and/or renneting, and processed up to moulding without extended drainage [38, 103]. Prior heat-treatment of the milk, resulting in formation of aggregates of denatured whey proteins and $\kappa$-casein prior to concentration, may be used to prevent the loss of the concentrated whey proteins during syneresis [49]. Pre-concentration of whey using UF, prior to its addition to milk and concentration into liquid pre-cheese [29] or to UF-concentrated milk [151] have also been proposed to increase whey protein recovery in the cheese curd.

A major drawback of the UF concentration of cheese milk is the increase in the 
buffering capacity of the retentates, because of the concentration of colloidal calcium phosphate. Satisfactory corrections are possible through acidification of the milk prior to concentration, or increase in ionic strength by addition of sodium chloride during or after concentration [75, 111]. Both methods induce the solubilisation of calcium ions, either through reducing ionisation of the phosphoseryl groups of the casein molecules, or displacement of calcium by sodium within the micelles [20, 88]. Addition of sodium chloride to the retentate will also prevent coagulation during the UF process, especially in the case of heated milk that is acidified prior to or during UF. Replacement of calcium by sodium induces an increase in the surface charge, voluminosity and hydration of the casein micelles; and the increased ionic strength of the medium will lower their apparent isoelectric $\mathrm{pH}$ [39]. These effects of $\mathrm{NaCl}$ addition therefore ensure a higher stability of the milk system to environmental changes.

For the above reasons, the most successful development of UF cheeses, in particular made with heated milk, have been highmoisture, low-pH white cheeses such as Quarg and Cast Feta. In the latter case, UF concentration of heated milk improves smoothness of the curd [87] and processing of the curd directly in its retail package prevents fine losses [112]. Alternatively, ultrafiltration can be performed after the complete acidification and renneting of the milk, to make fresh cheeses or cream cheeses. Positive relationships have been reported between the amount of heat-denatured whey protein in the starting milk, and increased viscosity of the fresh cheeses $[81,82,101]$.

\subsection{Whey cheeses}

The whey proteins present in by-products of traditional cheese-making may also be recovered through the preparation of specific traditional whey cheeses made from the concentration of whey, or of a mix of whey and milk, and moulding of the concentrate [42]. Recent reviews have made a distinction between two processes for making whey cheeses [45]. A first group of whey cheeses may be prepared by the com- bined heating and evapo-concentration of a mixture of whey and milk, until Maillard browning and a high viscosity are reached, then moulding of the concentrated product. The sugars crystallise on further cooling, to give the appropriate texture of the products. Theses cheeses are essentially produced in Scandinavian countries, e.g. Mysost in Norway, and in some Mediterranean countries like Greece, which produces Mytzrithra $[56,135]$.

The second group of whey cheeses, that includes Ricotta in Italy, Sérac or Brousse in France, and Brocciu in Corsica, are produced by the heat-treatment of sweet whey, with or without added milk, concentrated or not, at temperatures of $80-95^{\circ} \mathrm{C}$ for 30 to $45 \mathrm{~min}[56,127]$. The whey proteins extensively denature and aggregate until flocs are formed that can be easily collected by filtration or centrifugation. The precipitate can be further acidified by addition of an acidulant or of lactic acid bacteria.

Whey cheeses comply with different standards than those that apply to cheeses. The distinction is essentially based on the casein to whey protein ratio of the starting dairy material, that should be equal to or higher than that of milk in standard cheeses [41], and lower in that of whey cheeses [42]. Also, the manufacture of standard cheeses involves the coagulation of the milk protein, in particular, the casein fraction, by rennet or another coagulating enzyme to form a gel or into any other end-product having similar textural and chemical properties [41].

\section{THE USE OF pH AS A MEANS TO CONTROL THE FORMATION OF HEAT-INDUCED MILK PROTEIN AGGREGATES}

\subsection{Disulphide bonds, number and size of the heat-induced protein aggregates}

Various studies have reported the strong impact of $\mathrm{pH}$ on the denaturation and aggregation of the whey proteins. The denaturation rates of $\alpha$-lactalbumin and $\beta$-lactoglobulin in milk heated at $80^{\circ} \mathrm{C}$ both increased with $\mathrm{pH}$ from 5.5 to 8.8 , although the two proteins 
Table I. Changes in the properties of the heat-induced protein aggregates formed in model solutions of whey protein, in whey protein isolate (WPI) or in milk, as the $\mathrm{pH}$ of heat-treatment increases towards alkaline values.

\begin{tabular}{|c|c|c|c|}
\hline Property of the aggregates & $\begin{array}{l}\text { Variation as } \mathrm{pH} \\
\text { increases }\end{array}$ & $\begin{array}{l}\mathrm{pH} \text { range } \\
\text { studied }\end{array}$ & References \\
\hline Concentration & Increases & $\geq 6.5$ & [57] (skim milk), $[66,68,163](\beta-\lg )$ \\
\hline $\begin{array}{l}\text { Proportion of covalent } \\
\text { bonds in the aggregates }\end{array}$ & Increases & $\geq 6.5$ & [67] ( $\beta-\lg ),[113](\mathrm{WPI})$ \\
\hline Size & Decreases & {$[6.3-8.0]$} & $\begin{array}{c}{[66-68](\beta-\lg ),[4,128],[156]} \\
\text { (skim milk) }\end{array}$ \\
\hline $\begin{array}{l}\text { Proportion of aggregates } \\
\text { bound to the casein micelles }\end{array}$ & Decreases & {$[6.5-7.5]$} & $\begin{array}{c}{[4-6,57,117,139-141],[156]} \\
\text { (skim milk) }\end{array}$ \\
\hline $\begin{array}{l}\text { Proportion of } \kappa \text {-casein } \\
\text { in the aggregates }\end{array}$ & Increases? & {$[6.3-6.9]$} & [156] \\
\hline
\end{tabular}

had different profiles of sensitivity against $\mathrm{pH}$ [85].

In model solutions of $\beta$-lactoglobulin $[66,68,163]$ or in skim milk [57], heated at $\mathrm{pH}$ values in the maximum range 3 to 10 , heat-induced protein aggregates were formed at all $\mathrm{pH}$ values. The aggregation rate increased with $\mathrm{pH}$ values in the range 6.5 to 8.0 , so that more aggregates were formed at $\mathrm{pH} 7.0$ or 8.0 than at $\mathrm{pH} 6.5$ [66, $68]$. The reactivity and accessibility of the free thiol of $\beta$-lactoglobulin was higher at $\mathrm{pH} 8.0$ than at 7.0, as a result of the proximity of the pK value of the thiol $(\sim 8.2)$ [66]. As a result, the conversion of thiols into disulphide bonds increased with $\mathrm{pH}$ up to at least 6.9 [163] or up to $\mathrm{pH} 11$ [113], as did the contribution of intermolecular disulphide bonds in the formation of heatinduced protein aggregates of $\beta$-lactoglobulin [67] or of $\kappa$-casein and whey protein in milk [57]. Conversely, the contribution of electrostatic interactions decreased as $\mathrm{pH}$ increased, as a result of the increased negative charge of the $\beta$-lactoglobulin (isoelectric $\mathrm{pH} \sim 5.4$ ) [67].

The effect of highly alkaline $\mathrm{pH}$ values on the denaturation and sulphydryl-mediated polymerisation of whey proteins has been reported to occur even in the absence of heating, so that high molecular-weight aggregates were formed at $22{ }^{\circ} \mathrm{C}$ in solutions of whey protein isolate at $\mathrm{pH} 9$ and 11 [113]. This property was exploited by Con- nolly [25] in the manufacture of co-precipitates of casein and whey proteins after a short exposure of milk materials to $\mathrm{pH} 9$ to 11 , and subsequent precipitation at acidic $\mathrm{pH}$ values.

The analysis of heat-induced aggregates of $\beta$-lactoglobulin by size-exclusion chromatography, light scattering, or gel electrophoresis, showed that the molecular mass of the aggregates was about ten-fold smaller (decrease from $10^{6}$ to $10^{5}$, or from $10^{7}$ to $10^{6} \mathrm{~g} \cdot \mathrm{mol}^{-1}$, depending on conditions) as the $\mathrm{pH}$ of heat-treatment was increased from 6.5 to 8.0 [66-68]. A negative relationship between the $\mathrm{pH}$ of heat-treatment and the size of the heat-induced aggregates was also reported for the aggregates formed on the surface of casein micelles, in milk at pH 6.35 to 6.90 [156] or 6.5 to 6.7 [4], and for those formed in the serum phase of milk at $\mathrm{pH} 6.5$ to 7.2 [128], but not at $\mathrm{pH} 6.7$ to 6.9 [156]. Hoffmann and Van Mil [67] suggested that conditions favourable to disulphide bonding at high $\mathrm{pH}$ values, and therefore to termination reaction (e.g. SH/ SH oxidation, [113]), and to over-aggregation through hydrophobic interactions at low $\mathrm{pH}$ values, could account for the relationship of the size of the heat-induced whey protein aggregates with $\mathrm{pH}$.

These results, summarised in Table I, therefore indicate that the heat-induced aggregates of whey proteins form at a faster rate, and in greater amounts, as the $\mathrm{pH}$ of 
<smiles>O=[Se]1CC[Se]CC[Se]C1</smiles>

pH 6.35

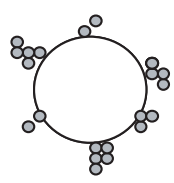

pH 6.45

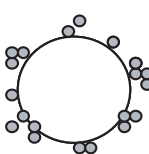

pH 6.55

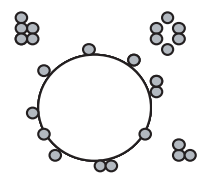

œ

pH 6.70

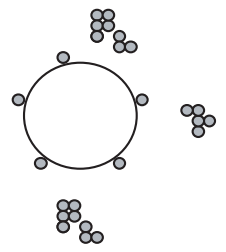

pH 6.90

Figure 1. A schematic representation, by Vasbinder and De Kruif [156], of the interactions between casein micelles and whey proteins occurring in milk during heat treatment for $10 \mathrm{~min}$ at $80^{\circ} \mathrm{C}$ at $\mathrm{pH}$ values ranging from 6.35 to 6.90 . The small circles represent heat-induced whey protein aggregates, the large circles represent casein micelles. Native whey proteins are not included.

heat-treatment increases. They are also smaller, and richer in covalent disulphide bonds, as $\mathrm{pH}$ increases. Further information, e.g. on the effect of the $\mathrm{pH}$ of heat-treatment on the initial stages of denaturation of the whey proteins, can be found elsewhere [35].

\subsection{Dissociation of $\kappa$-casein and distribution of the heat-induced protein aggregates}

Early studies on the stability of heattreated or UHT-treated skim milk showed that $\kappa$-casein dissociated more extensively from casein micelles during heating at $\mathrm{pH}$ $>6.9$, than at lower $\mathrm{pH}$ values [140, 141]. Because they interact with $\kappa$-casein upon heating, the denatured whey proteins remain in the serum phase when the heattreatment is performed at $\mathrm{pH}>6.9$, whereas a high proportion of them can be sedimented with the casein micelles by ultracentrifugation when the heat-treatment is performed at lower $\mathrm{pH}$ values [57, 117, 139-141]. Virtually no aggregates could be found in the serum phase of milk at $\mathrm{pH}<6.7$ [156]. Other studies showed a strong relationship between the $\mathrm{pH}$ of milk and the proportion of $\beta$-lactoglobulin attached to the casein micelles upon heating. In skim milk heated at $90{ }^{\circ} \mathrm{C}, 70-80 \% \mathrm{w} / \mathrm{w}$ of the $\beta$-lactoglobulin was bound to the micelles at $\mathrm{pH} 6.5$, versus $30 \% \mathrm{w} / \mathrm{w}$ at $\mathrm{pH} 6.7$, and $10 \% \mathrm{w} / \mathrm{w}$ at $\mathrm{pH} 7.1$ [4-6]. In skim milk heated at $80{ }^{\circ} \mathrm{C}, 60 \% \mathrm{w} / \mathrm{w}$ of the $\beta$-lactoglobulin was bound to the micelles at $\mathrm{pH}$
6.55 , versus $30 \% \mathrm{w} / \mathrm{w}$ at $\mathrm{pH} 6.9$ [156]. In concentrated milk heated at $120^{\circ} \mathrm{C}, 40 \%$ w/w of the whey protein was bound to the micelles at $\mathrm{pH} 6.55$, versus $25 \%$ at $\mathrm{pH} 6.85$ [139]. At a defined extent of denaturation of the whey protein, the hydrodynamic diameters of the casein micelles after heating decreased with increasing $\mathrm{pH}$ of heat-treatment, which was attributed to the binding of less numerous and/or smaller whey protein/ $\kappa$-casein aggregates to the surface of the micelles $[4,7]$.

All these results clearly show that the higher the $\mathrm{pH}$ of heat-treatment, the higher the dissociation rate of $\kappa$-casein, and the more heat-induced aggregates found in the serum phase, rather than on the surface of the casein micelles (Fig. 1, Tab. I).

However, it is not yet established whether the formation of heat-induced aggregates in the serum phase of milk is a cause, or a consequence, of the heat-induced dissociation of $\kappa$-casein. On the basis that the dissociation rate of $\kappa$-casein did not increase as fast as the proportion of heatinduced serum aggregates as a function of $\mathrm{pH}$, Anema and Li [5] suggested that the increased negative charge of the casein micelles at higher $\mathrm{pH}$ values prevented the denatured whey protein from interacting with the surface of the casein micelles, so that dissociation of $\kappa$-casein should precede its interaction with the whey protein in the serum phase. Conversely, other studies have reported a positive relationship between the amount of $\beta$-lactoglobulin in the milk, 
and the dissociation rate of $\kappa$-casein, to the extent that blocking the free thiol group of $\beta$-lactoglobulin with $N$-ethylmaleimide (NEM) prevented the extensive dissociation of $\kappa$-casein upon heating [3, 141]. Furthermore, a positive relationship has been demonstrated between the $\mathrm{pH}$ of heat-treatment, and the heat-induced dissociation of the caseins, especially $\kappa$-casein [2, 139]. $\kappa$-Casein dissociated to a greater extent as the $\mathrm{pH}$ and the temperature of heat-treatment increased, especially $>60^{\circ} \mathrm{C}$ [2]. The current hypothesis that would best explain most of these results is that the $\kappa$-casein dissociated upon heating is prevented from returning to the surface of the micelles because it aggregates with denatured whey proteins in the serum phase. However, the possibility that the denatured whey proteins that attach on the surface of casein micelles actively contribute to dissociation of the $\kappa$-casein cannot be ruled out. It is also possible that differently glycosylated forms of $\kappa$-casein dissociate differently [50].

Vasbinder and De Kruif [156] have demonstrated that the coating of the casein micelles by heat-induced aggregates of denatured whey protein and micellar $\kappa$-casein become less and less homogenous as $\mathrm{pH}$ decreases from 6.90 to 6.35 , with larger aggregates binding to less numerous $\kappa$-casein sites (Fig. 1). At a defined extent of denaturation of the whey proteins, these results suggest that larger heat-induced aggregates have a higher whey protein to $\kappa$-casein ratio, in agreement with the compositions of heat-induced aggregates found in the serum of heated control and caseindepleted milk [62].

\section{DETRIMENTAL EFFECTS OF HEAT-TREATMENT ON THE CHEESE-MAKING PROPERTIES OF MILK AND THE POTENTIAL OF HEATING MILK AT ALKALINE pH VALUES}

\subsection{Rennet coagulation properties of heated milk}

The heat-treatment of cheese milk for reasons of food safety or for the recovery of the whey proteins generally induces an increase in the rennet coagulation time (RCT); this is also true when a mixture of already denatured and aggregated whey protein and milk is heated [60]. The formation of heat-induced aggregates of denatured whey proteins and $\kappa$-casein on the surface of the casein micelles seems responsible for the inhibition of the renneting process in heated cheese milk [114, 120, 164]. Displacement of these heat-induced aggregates into the serum phase of milk upon heating milk at $\mathrm{pH}>6.9$ may therefore be an interesting means to reduce the detrimental effect of heating on the RCT of milk. The effect of such distribution of the heatinduced aggregates on the RCT may compare with that of the addition of "particulated" heat-denatured whey proteins to cheese milk on the RCT $[48,96]$ and would reduce the decrease in the curd firming rate and final strength of the gels observed with such addition as a consequence of the replacement of part of the casein, as the effective gel-forming protein fraction, by whey proteins $[48,149,150]$. Heat-treatment of milk at alkaline $\mathrm{pH}$ would also generate particles with sizes well below the 8 to $10 \mu \mathrm{m}$ limit $[76,128]$ at which particles physically hinder formation of the rennet gel instead of improving its texture through being "inert fillers" in the network [74, 149].

Both the primary and secondary phases of the rennet coagulation process are affected by heat-treatment. In milk at its natural $\mathrm{pH}$ value, Van Hooydonk et al. [154] and Ferron-Baumy et al. [49] have shown that the initial velocity, $\mathrm{Vi}$, of the primary phase of the action of rennet was 20 to $25 \%$ slower when the whey proteins were extensively denatured (heat-treatment exceeding $90{ }^{\circ} \mathrm{C}$ for $5 \mathrm{~min}$ ), compared with unheated milk. Van Hooydonk et al. [154] also showed that the amount of hydrolysable $\kappa$-casein was reduced by $10 \% \mathrm{w} / \mathrm{w}$ after heat-treating skim milk at $120{ }^{\circ} \mathrm{C}$ for $5 \mathrm{~min}$. Partial inhibition of the primary phase of the action of rennet on milk can be accounted for by the steric hindrance and the changes in electronegativity of the surroundings of the $\mathrm{Phe}_{105}-\mathrm{Met}_{106}$ bond of $\kappa$-casein, induced by the binding of heat-denatured whey proteins on the casein molecule [49]. 
The increased extent of heat-induced dissociation of $\kappa$-casein at alkaline $\mathrm{pH}$, in combination with the increased formation of soluble heat-induced whey protein/Кcasein aggregates described earlier, may allow a better access of the enzyme to the Phe $_{105}-$ Met $_{106}$ bond, despite the occurrence of denatured whey proteins, although this may depend on the structure of the aggregates. It is also a possibility that micelles depleted in $\kappa$-casein after heattreating the milk at $\mathrm{pH}>6.9$ may be destabilised at a lower level of proteolysis than required for control micelles.

Van Hooydonk et al. [154] and Vasbinder et al. [158] also reported a large inhibitory effect of the heat-treatment of milk on the secondary phase of the rennet action, i.e., on the aggregation and gelation of the casein micelles. As a consequence of their coating by denatured whey proteins, the casein micelles of heated milk have a lower surface hydrophobicity [92], thus lowering the potential for interaction. Their spherical shape may also be retained longer than for untreated micelles, therefore preventing fusion, as suggested by the microstructure of rennet gels of heated and control milks observed by scanning electron microscopy $[102,120]$. It is possible that milk heated at alkaline $\mathrm{pH}$ values, where less (hydrophilic) $\kappa$-casein and less heat-induced protein aggregates remain on the surface of the micelles, would show a reduced inhibition of the secondary phase of rennet coagulation.

An alternative explanation for the heatinduced increase in the rennet coagulation time of heated milk is the precipitation onto the casein micelles of the soluble calcium and phosphate ions during heating, to create a quasi-irreversibly insoluble tricalcium phosphate form, as suggested by Ustunol and Brown [152]. These authors reported an increase in the RCT of milk submitted to prolonged heating at 25 or $50{ }^{\circ} \mathrm{C}$, i.e., at temperatures lower than those required to induce the denaturation of, e.g., $\beta$-lactoglobulin. This calcium-dependent inhibition of the renneting process is accounted for by the lack of screening effect of soluble calcium on the casein micelle, and therefore the increase in their net repulsive charge and related stability. Van Hooydonk et al.
[154] further indicated that the relative insolubility of the heat-induced form of calcium phosphate would induce changes in the mineral equilibrium of milk, promoting the depletion of the casein micelle in colloidal calcium phosphate and therefore the formation of softer rennet casein gels. These changes in mineral equilibrium of heated milk could be at the origin of the socalled "rennet hysteresis" of heated milk, where the RCT of heat-treated milk is further increased by a prolonged storage in the cold [114, 154]. Heat-treatment [162] and alkalinisation of the milk [153] both decrease the proportion of soluble calcium (and phosphate) ions, thus increasing the detrimental effects of these changes on the formation of rennet gels, although one application of alkaline heat-treatment in order to reduce milkstone can be mentioned [46]. However, the effects of calcium and phosphate changes on the inhibition of the rennet action in heated milk are generally regarded as lower than those induced by the formation of heat-induced protein aggregates on the surface of the casein micelles $[95,154,158]$, albeit this is still debated [133].

Controversial results have been reported in the literature on the effect of heat-treating milk at $\mathrm{pH} 7.5$, rather than 6.7, on the rennet coagulation time. Absence of rennet coagulation of a milk sample heated at $90^{\circ} \mathrm{C}$ for $10 \mathrm{~min}$ at $\mathrm{pH} 7.5$, then neutralised to $\mathrm{pH} 6.7$ for $24 \mathrm{~h}$ at $5{ }^{\circ} \mathrm{C}$, was reported [154]. The heat-treatment of skim milk at $90{ }^{\circ} \mathrm{C}$ for $30 \mathrm{~s}$, at $\mathrm{pH}$ values ranging from 6.0 to 9.0 , induced little variations in the kinetics of the primary phase of the renneting reaction, as long as $\mathrm{pH}$ was below 7.3 [89]. At heattreatment $\mathrm{pH} \geq 7.3$, Leaver et al. [89] reported a decrease in the rate of rennet action up to $\mathrm{pH} 7.8$, followed by an increase at higher $\mathrm{pH}$ values.

On the other hand, the RCT of skim milk heated at $72{ }^{\circ} \mathrm{C}$ for $16 \mathrm{~s}$ and at $\mathrm{pH} 7.2$, then acidified to $\mathrm{pH} 6.4$, was only $\sim 6 \mathrm{~min}$, versus $\sim 22$ min for skim milk heated, and renneted, at $\mathrm{pH} 6.7$ [71]. Rennet coagulation times $<6$ min were obtained after $\mathrm{pH}$ cycling milk heated at $\mathrm{pH} 7.5$, to $\mathrm{pH} 5.5$ at $4{ }^{\circ} \mathrm{C}$, then to $\mathrm{pH} 6.2$ or 6.4 prior to renneting [71]. Among various samples of heated 
skim milk, those heated at $\mathrm{pH} 7.3$, then $\mathrm{pH}-$ cycled, showed maximum rennet coagulation properties, although not as good as those of raw milk [142]. These studies tend to show a positive effect of heat-treating milk at $\mathrm{pH}>6.7$ on the RCT, albeit in most cases the effect of such alkaline heat-treatment could not be clearly distinguished from the effect of post-heating treatments, such as acidification or $\mathrm{pH}$-cycling. When renneting was performed directly on the milk samples, without particular treatment following heating at $80^{\circ} \mathrm{C}$ for $10 \mathrm{~min}$ at $\mathrm{pH}$ values ranging from 6.35 to 6.90 , it was, however, found that the milk samples heated at pH 6.90 gelled earlier and gave stronger rennet gels than milk heated at $\mathrm{pH}$ 6.70 , as a result of the larger proportion of aggregates to be found in the serum phase rather than on micellar $\kappa$-casein [156].

\subsection{Quality of cheeses made with heated milk}

The heat-treatment of milk at temperatures allowing the denaturation of the whey proteins significantly increases the cheese yield, through the increases in the protein yield and moisture content of the curd. In Cheddar cheeses, the studies reported a slight increase in fat yield, a +2.5 to $+8 \%$ w/ $\mathrm{w}$ increase in protein yield, and a +2.5 to $+5 \% \mathrm{w} / \mathrm{w}$ increase in humidity after heattreating the cheese milk at $\sim 90{ }^{\circ} \mathrm{C}$ for up to $1 \mathrm{~min}[10,72,142]$. In Havarti cheese, heat-treating the milk at $85{ }^{\circ} \mathrm{C}$ for $17 \mathrm{~s}$ led to an increase in protein yield $(+2 \% \mathrm{w} / \mathrm{w})$ and in humidity ( $+3 \% \mathrm{w} / \mathrm{w})$ of the curd [93]. Heat-treating the milk at $91{ }^{\circ} \mathrm{C}$ for $16 \mathrm{~s}$ at an alkaline $\mathrm{pH}$ value of 7.5 also helped increase the protein yield of Cheddar cheeses, despite a slightly higher loss of fines during drainage, compared with control milk at either natural $\mathrm{pH}$ or $\mathrm{pH} 7.5$ [72]. In Cheddar cheeses made with milk heated at $90{ }^{\circ} \mathrm{C}$ for $30 \mathrm{~s}$, more whey proteins were denatured, and more were recovered in the rennet curd, whose total protein content increased as the $\mathrm{pH}$ of heat-treatment increased in the range 6.5 to 8.7 [12]. In the light of the work of, e.g., Vasbinder and De Kruif [156] or Renan et al. [128], these results suggested that despite the higher proportion of heat-induced whey protein/ $\kappa$-casein aggregates formed in the serum phase of heated milk at alkaline $\mathrm{pH}$ values, these aggregates were retained in the cheese curd upon renneting, cutting and drainage. A slight tendency for increased moisture content could be noticed in cheeses made from milk heated at $\mathrm{pH}>7.5$, compared with the lower $\mathrm{pH}$ of heat-treatment [12].

However, the organoleptic qualities of the cheeses, especially texture and flavour, may be affected by the heat-treatment of the milk. The curds of Cheddar cheeses made with heated milk are generally crumbly, and can be difficult to process mechanically $[10,12,102]$. The firmness of fresh curds, obtained by renneting heated milk at $\mathrm{pH}$ 6.6, was reported to be inversely correlated to the rate of whey protein denaturation [60], although increased heating temperature from 80 to $130{ }^{\circ} \mathrm{C}$ prior to the manufacture of Mozzarella cheese (renneting $\mathrm{pH}$ $\sim 5.6$ ) resulted in greater firmness of the cheeses, possibly as a result of a bias with the solid-not-fat content [132]. The firmness of ripened Cheddar cheeses made with heated milk generally compared with cheeses made with pasteurised milk [10, 12, 13]. Moderate high temperature-short time heat-treatment was also reported to smoothen the texture of white soft cheese made from UF-concentrated whole milk; longer heating times resulting in mealiness [137]. The increased retention of water in the cheese curd due to the high water-binding capacity of denatured whey proteins may be detrimental to drainage, curd fusion and firmness, and therefore to the manufacture of hard cheeses such as Cheddar cheese [129] and model semi-hard cheeses similar to Gouda, Provolone, Havarti or Halloumi [58]. Conversely, satisfactory textures were reported when manufacturing semi-hard cheese such as Cheshire using milk heated at $97{ }^{\circ} \mathrm{C}$ for $15 \mathrm{~s}$, providing adjustments of the standard process [102]; or soft cheeses such as Camembert using milk heated at temperatures up to $80^{\circ} \mathrm{C}$ for 1 to $3 \mathrm{~min}$ [9, 54] or UHT-treated milk [17]. A high water-binding capacity, a low proteolysis and strong covalent bonds as introduced by denatured, aggregated whey proteins during the heat-treatment of milk, are especially 
beneficial to the yield, taste and texture of fresh acid cheeses such as quarg, or fromage frais $[65,74,81,82,87,95,99,101]$.

The functional properties of cheeses made with heated milk may also be adversely affected by the occurrence of whey proteins in the curd. Cheddar [10,12] or Mozzarella cheese [64] made with cheese milk that included heat-denatured whey proteins showed impaired melting and stretching capacity, and reduced oilingoff as a result of an increased interaction between fat and protein [10], changes in the protein matrix of the curd, or the binding of water and calcium by the denatured whey proteins [74]. Similar effects have been reported in the presence of native whey proteins in UF-Mozzarella cheese [100], and may be explained by the denaturation of these proteins during cooking [112].

Heat-treatment of cheese milk may also induce sensible changes in the flavour profiles of cheeses. Reduction in free fatty acid production can be observed in milk lacking their endogenous microbial flora [58, 80], despite the fact that high heat-treated milk generally yields better acid production by lactic acid bacteria than raw milk, as reviewed by Feldstein and Westhoff [47]. Flavour changes also include modification of the free amino acid and peptidic profiles released during ripening of semi-hard cheeses [58] or of a range of soft to hard cheeses [83]. The release of peptides after 3 months of ripening, in Cheddar cheeses made with heated milk, was reported to benefit from adjustment of the milk to alkaline $\mathrm{pH}$ values prior to heating. As the $\mathrm{pH}$ of heat-treatment increased in the range 6.0 to 8.7 , the peptide profile of the cheeses resembled more closely that of a control Cheddar cheese, made from simply pasteurised milk; as a result, Cheddar cheeses made from milk heated at $90{ }^{\circ} \mathrm{C}$ for $30 \mathrm{~s}$ at alkaline $\mathrm{pH}$ were more acceptable than when heated at lower $\mathrm{pH}$ values [12]. The development of the typical Cheddar flavour was also higher in cheeses made with milk heated at $\mathrm{pH} 7.1$ and 7.5, compared with milk heated at pH 6.7 or even with control pasteurised milk [12]. The cheeses were more crumbly when prepared with heated milk, but this character was reduced at heat- treatment $\mathrm{pH}$ of 7.1 or 7.5 . Poor melting properties were reported, whatever the $\mathrm{pH}$ of heat-treatment. It was also reported that the flavour defects of the Cheddar cheeses made from heated, $\mathrm{pH}$-adjusted milk developed faster than their qualities, so that the same cheeses, aged 9 months, were less acceptable than at 3 months of age [12]. Heating milk at alkaline $\mathrm{pH}$ also generated less proteinaceous fouling of the heating vessel, and less cooked flavour of the cheese milk, than at lower $\mathrm{pH}$ values [72].

The key effects of the recovery of whey protein in cheese using heat-denatured whey proteins, on the rennet coagulation properties of cheese milk and on cheese quality, are summarised in Table II. The increase in moisture content of cheeses containing denatured whey proteins is omitted because its qualification as advantage or drawback depends on the variety of cheese produced. Table II stresses that only a small number of studies have investigated the effects of alkaline $\mathrm{pH}$ of heat-treatment in cheese technology.

Although the heating conditions of milk may be easy factors to control, it should be borne in mind that heat-treatment induces intricate and complex changes not only in the form and distribution of the denatured whey proteins, but also in the $\mathrm{pH}$ and buffering properties of the milk, respectively due to the transformation of lactose through the Maillard reaction and formation of formic acid [24], and to calcium phosphate precipitation [97]. These environmental changes are in turn very likely to influence the protein system, and hence the formation and properties of the whey protein/ $\kappa$-casein heat-induced aggregates (Sect. 3, this review) and properties of the curd. Guinee et al. [58] have, for instance, reported that the higher the heat-treatment of cheese milk, the lower the $\mathrm{pH}$ measured in semi-hard cheeses from day 1 and throughout ripening. This could account for some heatinduced changes in the cheese texture, e.g. coarseness and mealiness, otherwise attributed to the interaction of denatured whey proteins with casein micelles. Heat-treatment of the milk prior to cheese-making, and/or the subsequent $\mathrm{pH}$, structural mineral and protein changes of the milk and 
Table II. Key advantages and drawbacks of the three approaches presented in this review that use heat-denatured whey proteins in order to increase cheese yield. RCT: rennet coagulation time, WP: whey proteins, 3 : casein micelles, O: whey protein, O: $\kappa$-casein and ${ }^{2}$ : "particulated" whey proteins.

\begin{tabular}{|c|c|c|c|}
\hline $\begin{array}{l}\text { Method applied } \\
\text { to the milk }\end{array}$ & $\begin{array}{l}\text { Representation of the dairy } \\
\text { system }\end{array}$ & Advantages & Drawbacks \\
\hline $\begin{array}{l}\text { Heat-treatment } \\
\text { at natural } \mathrm{pH}\end{array}$ & $\begin{array}{l}80 \\
88\end{array}$ & $\begin{array}{l}\text { - Increased cheese yield } \\
{[10,72,93,142]}\end{array}$ & $\begin{array}{l}\text { - Increased RCT and } \\
\text { decreased curd fusion due to } \\
\text { the coating of the casein } \\
\text { micelles by WP }[114,120,164] \\
\text { - Crumbly, soft texture of the } \\
\text { curd }[10,12,60,102] \\
\text { - Poor melting properties }[10, \\
12,64] \\
\text { - Changes in proteolysis and } \\
\text { flavour profile }[14-16,58,74]\end{array}$ \\
\hline $\begin{array}{l}\text { Addition of } \\
\text { "particulated" } \\
\text { whey protein }\end{array}$ & & $\begin{array}{l}\text { - Minimal increase of the } \\
\text { RCT }[48,96] \\
\text { - Fat substitute }[96,125] \\
\text { - Increased cheese yield } \\
{[96,107]}\end{array}$ & $\begin{array}{l}\text { - Decreased gel firming rate } \\
\text { and final strength due to the } \\
\text { decrease of the concentration } \\
\text { of casein }[48,149,150] \\
\text { - Crumbly, soft texture of the } \\
\text { curd }[48,96] \\
\text { - Poor melting properties } \\
\text { [107] }\end{array}$ \\
\hline $\begin{array}{l}\text { Heat-treatment } \\
\text { at alkaline } \mathrm{pH}\end{array}$ & $880 \sum_{80} \sum_{80}$ & $\begin{array}{l}\text { - Heat-denatured WP in } \\
\text { the serum phase rather } \\
\text { than on micelles }[4-6, \\
57,117,139-141,156] \\
\text { - Decreased RCT on } \\
\text { combination with pH- } \\
\text { cycling }[71,142] \\
\text { - Increased cheese yield } \\
{[12,72]} \\
\text { - Reduced flavour and } \\
\text { texture drawbacks of milk } \\
\text { heated at natural pH [12] }\end{array}$ & $\begin{array}{l}\text { - Inhibited primary phase of } \\
\text { renneting [89] and increased } \\
\text { RCT [154] } \\
\text { - Crumbly, soft texture of the } \\
\text { curd [12] }\end{array}$ \\
\hline
\end{tabular}

curd, may also influence growth of the micro-organisms $[47,58]$ and activity of the enzymes, both with potentially important consequences on texture and flavour of the cheeses. Depending on conditions, proteolysis of the $\alpha_{s}$-and $\beta$-caseins by plasmin may be reduced $[14,15,146]$ or increased $[16$, $22,77]$. Various factors have been proposed to account for these changes, including the heat-denaturation of plasmin or plasminogen $[14,15,146]$, or of an inhibitor thereof
$[16,22,77]$. Native $[63,90,112]$ or denatured whey proteins in cheese curds are thought to inhibit proteolysis of $\beta$ - and/or $\alpha_{\mathrm{s}}$-caseins by plasmin and/or chymosin [74, 93], e.g. through plasmin/ $\beta$-lactoglobulin heat-aggregation [78]. Mistry and Kasperson [111] suggested that a higher moisture content of the cheeses, as induced by the incorporation of denatured whey protein, enhances the activity of plasmin and residual chymosin in the curd. The whey proteins themselves 
did not appear to be hydrolysed during renneting or ripening of the cheeses, whether they were in native or denatured form [13, $74,100,131]$. Promotion or inhibition of primary proteolysis will affect the development of bitterness in cheeses made from heated milk, but also curd fusion, ripening, and melting properties of the cheeses, based on yet debated mechanisms that do not always involve the heat-denatured whey proteins. UF concentration of cheese milk is eventually known to increase the buffering capacity of the cheese curd and to influence growth and lysis of the ripening microorganisms [55]. Its use in combination with heat-treatment to recover the whey proteins in cheese may generate effects on texture and flavour that are independent of properties of the denatured whey proteins. Care should therefore be taken as to interpret the direct effects of heat-treatment and $\mathrm{pH}$ changes on cheese quality.

\subsection{Technological means used to restore the cheese-making properties of heated milk}

Various approaches have been proposed in the literature to attempt to restore the cheese-making properties of heated milk. It is, for instance, a common practice to increase the level of ionic calcium, usually by addition of up to $0.3-0.6 \mathrm{~g} \cdot \mathrm{L}^{-1}$ calcium chloride, depending on the intensity of heattreatment $[10,143]$. Ionic calcium screens the charges on the casein micelles and reduces the interparticle repulsion, thus favouring flocculation; it also helps increase the gel strength by forming calcium bonds between phosphocasein molecules in the rennet gel. In the case of milk heated at alkaline $\mathrm{pH}$, where significant precipitation of calcium phosphate is expected, it is essential to maintain an adequate concentration of soluble calcium.

Acidification of the milk prior to renneting is another means to increase the concentration of ionic calcium by dissociating both colloidal, and heat-induced, insoluble calcium phosphate complexes. As the $\mathrm{pH}$ approaches 5.5, i.e., the $\mathrm{pH}$ of highest activity of chymosin, the rates of coagulation and firming of the rennet gel increase [19]. Banks et al. [11] and Banks [10] thus lowered the renneting $\mathrm{pH}$ of milk heated at $90{ }^{\circ} \mathrm{C}$ for $30 \mathrm{~s}$ or $1 \mathrm{~min}$ from $\mathrm{pH} \sim 6.5$ to 5.8 or 6.2 to make Cheddar cheese. However, acidification also increases association of the enzyme with the casein molecules [36], and therefore retention of the enzyme in the curd, where its strong activity leads to increased proteolysis $[27,51,69,159]$. This effect is more significant in rennet-type curds such as Cheddar [69], where acidification in conventional processes essentially follows a fast renneting step and is usually limited, than in soft cheeses where acidification starts prior to rennet addition and largely proceeds throughout the renneting process, curd development and drainage [51]. In Cheddar cheese, acidification of the milk prior to renneting also slows down lactic acid production by the lactic acid bacteria, resulting in inhibited flavour development [11]. Cycling the $\mathrm{pH}$ of heated milk has proven a most efficient alternative to increase the concentration of ionic calcium by the use of $\mathrm{pH}$ adjustment of the milk, without leading to excessive chymosin retention and proteolysis [71, 73, 143]. In this process, the heated milk is acidified to $\mathrm{pH} 5.5$ to 6.2 , stored at $5{ }^{\circ} \mathrm{C}$ for $24 \mathrm{~h}$ and eventually neutralised at $\mathrm{pH} 6.5$ to 6.7 prior to renneting [154]. Maximum rennet coagulation properties of heated milk were, for instance, reported through combining alkaline $\mathrm{pH}$ of heat-treatment, and $\mathrm{pH}$-cycling of the milk prior to enzyme addition [71, $142]$. Long storage in the cold may be avoided by acidification to $\mathrm{pH}$ values below 5.5 [97] or by using injection and depressurisation of $\mathrm{CO}_{2}$ to adjust the $\mathrm{pH}$ [61]. Lucey et al. [98] reported that milk that had been $\mathrm{pH}$-cycled to values lower than 5.5 and restored to 6.6, showed a decreased buffering property at $\mathrm{pH} \sim 5.1$ and higher calcium activity, indicating an increase in soluble ionic calcium. Furthermore, a buffering peak appeared at $\mathrm{pH} 6.3$ on back titration of pH-cycled milk, that the authors attributed to the precipitation of part of the dissociated calcium and phosphate ions into dicalcium phosphate dihydrate or octacalcium phosphate. This agreed with the suggestion by Van Hooydonk et al. [154] that the neutralisation 
step of the $\mathrm{pH}$ cycle may induce the re-formation of calcium phosphate complexes that are different in nature to those naturally found in (heated) milk. Lucey [95] and Guillaume et al. [61] further hypothesised that the destructuration of the casein micelles upon $\mathrm{pH}$-cycling make previously buried $\kappa$-casein molecules more accessible to hydrolysis by rennet.

Alternatively to exploiting the mineral balances of milk to restore the cheese-making properties of heated milk, other approaches make use of the protein fraction. Zoon [168] proposed only heating a fraction of a milk bulk or blending heated milk with raw milk so that unaffected $\kappa$-casein could take the lead in the renneting reaction kinetics. Vasbinder and De Kruif [156] have reported that milk heated at $\mathrm{pH} 6.35$ exhibited a rennet coagulation behaviour comparable with that of unheated milk. This would result from the more heterogeneous distribution of the denatured whey proteins on the surface of casein micelles as the $\mathrm{pH}$ of heat-treatment decreases, which leaves more $\kappa$-casein free of denatured whey proteins, and therefore accessible to chymosin.

More specifically, Delespaul and Remars [37], Quiblier et al. [126], Schreiber and Hinrichs [134] and Nelson and Barbano [115] extracted a large proportion of the whey proteins from the milk by either chromatography or membrane technology, respectively, so that the depleted milk could be heated without having the extensive interaction of heat-denatured whey protein with the $\kappa$-casein molecules, i.e., without increase in the RCT and quality decrease in the rennet gel. The co-product of such separation can also be heated to denature the whey protein, concentrated using UF, and added back to the casein fraction to make cheese with a high protein recovery and little modification of the rennet coagulation properties [105]. Concentration of heated milk by ultrafiltration techniques is another useful approach to restore the cheese-making properties of heated milk $[49,60,65$, $104,126,138,165,166]$. It is postulated that concentration reduces the distance between casein micelles, and hence increases the probability for interaction and bridge formation during renneting $[59,106$,
164]. This practice is especially recommended to make fresh or soft cheeses where high whey protein recovery is beneficial because it leads to a relatively high moisture content and a thick texture.

\subsection{Of the use of alkalis in cheese-making}

The use of alkalis, like any other food additive, is strictly controlled by policies (at national and supra-national levels, such as in the European Union) generally inspired by the norms released by the Codex Alimentarius. Alkalis generally proposed in patents using $\mathrm{pH}$ manipulation of dairy products to make dairy ingredients and dairy products, such as sodium, calcium or magnesium salts of hydroxide, oxide, carbonate and other substances [18, 145] fall under the Codex Alimentarius general standard for food additives [44]. However, the general standard for cheese [41] only authorises glucono- $\delta$-lactone, calcium carbonate and magnesium carbonate as acidity regulators, within the limits of the Good Manufacturing Practice (GMP). The addition of alkalis to milk in order to make cheese may therefore induce important restrictions of, e.g. designation of the product, unless otherwise enforced by national policies.

The addition of alkalis to milk, especially sodium salts, might also have important consequences on the nutritional value of the product, hence on its recommendation by the bodies in charge of food safety [1] and finally on its acceptance by today's healthconcerned consumers. Calcium and magnesium salts may meet nutritional recommendations better, although uses out of the standard regulation for cheese may fall under a category of enriched dairy products and should hence meet the specific standards for such products ([43] for the Codex Alimentarius), sometimes through a timeconsuming agreement procedure.

\section{CONCLUSION}

As outlined in the present review, the changes in the distribution of the heat-induced 
whey protein/К-casein aggregates, and in the dissociation rate of $\kappa$-casein, upon heating milk at alkaline $\mathrm{pH}$, may be an interesting, yet insufficiently investigated factor to use to incorporate the whey protein into the cheese curd with minimum deleterious effects on the rennet coagulation properties of the milk. Combination of alkaline heattreatment with other means such as UF concentration or calcium addition may improve some of the processes presently used to reach these goals, as demonstrated by the results on combined alkaline treatment and $\mathrm{pH}$-cycling of milk [72, 142]. At present, the heat-treatment of milk at alkaline $\mathrm{pH}$ values has found little application in the restoration of the rennet coagulation properties of heated milk. In most cases, such a process was used to induce whey protein aggregates or protein-calcium complexes not otherwise present in the unheated milk, giving ingredients with modified viscosity, calcium content, or lactose content [18], to increase the yield of isolation of whey protein/casein complexes [25] or to increase the solubility of the isolates upon reconstitution [57]. In some other cases, alkaline heat-treatment has been used as a preliminary to the use of transglutaminase [145], sometimes in combination with rennet [28] to manufacture dairy ingredients. In yoghurtmaking, heating at $\mathrm{pH} 7.1$ improves the acid gelation properties of the milk, and final firmness of the gel $[5,94]$. This review therefore demonstrates the need for further investigations to make use of the potential of alkaline heat-treatment of milk in order to increase retention of the whey proteins into cheese curds, as intended by Ménard et al. [108].

Acknowledgements: The author wishes to thank Magalie Weber, Rachel Boutrou and Jean-Louis Maubois for help during the writing of this manuscript, and Douglas Dalgleish for careful reading.

\section{REFERENCES}

[1] AFSSA, Recommandation du groupe de travail, in: Rapport du groupe de travail sur le sel (2002) 48-66.
[2] Anema S.G., Klostermeyer H., Heat-induced, $\mathrm{pH}$-dependent dissociation of casein micelles on heating reconstituted skim milk at temperatures below $100{ }^{\circ} \mathrm{C}$, J. Agric. Food Chem. 45 (1997) 1108-1115.

[3] Anema S.G., Li Y., Further studies on the heat-induced, $\mathrm{pH}$-dependent dissociation of casein from the micelles in reconstituted skim milk, Lebensm.-Wiss. Technol. 33 (2000) 335-343.

[4] Anema S.G., Li Y., Association of denatured whey proteins with casein micelles in heated reconstituted skim milk and its effect on casein micelle size, J. Dairy Res. 70 (2003) 73-83.

[5] Anema S.G., Li Y., Effect of pH on the association of denatured whey proteins with casein micelles in heated reconstituted skim milk, J. Agric. Food Chem. 51 (2003) 16401646.

[6] Anema S.G., Lee S.K., Lowe E.K., Klostermeyer H., Rheological properties of acid gels prepared from heated $\mathrm{pH}$-adjusted skim milk, J. Agric. Food Chem. 52 (2004) 337-343.

[7] Anema S.G., Lowe E.K., Lee S.K., Effect of $\mathrm{pH}$ on the acid-induced aggregation of casein micelles in reconstituted skim milk, Lebensm.Wiss. Technol. 37 (2004) 779-787.

[8] Asher Y.J., Mollard M.A., Thomson S., Maurice T.J., Caldwell K.B., Whey protein product method for its production and use thereof in foods, Patent WO92/20239, 1992.

[9] Bachmann H.P., Puhan Z., Grenzen fur die Hitzebehandlung von UF-teilkonzentrierter Milch in der Weichkaseherstellung (Limits of heat treatment of partially UF-concentrated milk in the manufacture of soft cheese), Schweiz. Milchwirtsch. Forsch. 20 (1991) 23-29.

[10] Banks J.M., Improving cheese yield by the incorporation of whey powder, Dairy Ind. Int. 55 (1990) 37-41.

[11] Banks J.M., Stewart G., Muir D.D., West I.G., Increasing the yield of Cheddar cheese by the acidification of milk containing heatdenatured whey protein, Milchwissenschaft 42 (1987) 212-215.

[12] Banks J.M., Law A.J.R., Leaver J., Horne D.S., Sensory and functional properties of cheese: incorporation of whey proteins by $\mathrm{pH}$ manipulation and heat treatment, J. Soc. Dairy Technol. 47 (1994) 124-131.

[13] Banks J.M., Law A.J.R., Leaver J., Horne D.S., The inclusion of whey proteins in cheese - an overview, in: Emmons D.B. (Ed.), Cheese yield and factors affecting its control, IDF Seminar in Cork, International 
Dairy Federation, Bruxelles, Belgium, Special Issue 9402, 1994, pp. 387-401.

[14] Benfeldt C., Sørensen J., Heat-treatment of cheese milk: effect on proteolysis during cheese ripening, Int. Dairy J. 11 (2001) 567-574.

[15] Benfeldt C., Sørensen J., Ellegard K.H., Petersen T.E., Heat treatment of cheese milk: effect on plasmin activity and proteolysis during cheese ripening, Int. Dairy J. 7 (1997) 723-731.

[16] Benfeldt C., Sørensen J., Petersen T.E., Inhibitory activity against plasmin, trypsin, and elastase in rennet whey and in cheese fortified with whey protein, J. Dairy Sci. 81 (1998) 615-620.

[17] Bergère J.-L., Cerf O., Procédé pour l'obtention de fromages à partir de lait soumis à un traitement thermique à une température supérieure à $100{ }^{\circ} \mathrm{C}$, Patent FR2357183, 1978.

[18] Blazey N.D., Knights R.J., Wu C., Membrane filtered milk proteins varying in composition and functional attributes, Patent WO00/51440, 2000.

[19] Brulé G., Lenoir J., The coagulation of milk, in: Eck A. (Ed.), Cheese-making. Science and technology, 2nd edn., Lavoisier Publishing Inc., New York, USA, 1987, pp. 1-21.

[20] Brulé G., Maubois J.-L., Fauquant J., Étude de la teneur en éléments minéraux des produits obtenus lors de l'ultrafiltration du lait sur membrane, Lait 54 (1974) 600-615.

[21] Buhler M., Olofson M., Fosseux P.-Y., Whey protein recovery, Patent US4265924, 1981.

[22] Calvo M.M., Leaver J., Law A.J.R., Banks J.M., Changes in casein levels during the ripening of Cheddar type cheese made from overheated milk, Milchwissenschaft 47 (1992) 516-518.

[23] Caussin F., Famelart M.-H., Maubois J.-L., Bouhallab S., Mineral modulation of thermal aggregation and gelation of whey proteins: from $\beta$-lactoglobulin model systems to whey protein isolate, Lait 83 (2003) 353-364.

[24] Chaplin L.C., Lyster R.L.J., Effect of temperature on the $\mathrm{pH}$ of skim milk, J. Dairy Res. 55 (1988) 277-280.

[25] Connolly P.B., Method of producing milk protein isolates and milk protein/vegetable protein isolates and compositions of same, Patent WO82/01641, 1982.

[26] Corredig M., Dalgleish D.G., The mechanisms of the heat-induced interaction of whey proteins with casein micelles in milk, Int. Dairy J. 9 (1999) 233-236.

[27] Creamer L.K., Lawrence R.C., Gilles J., Effect of acidification of cheese milk on the resultant Cheddar cheese, N. Z. J. Dairy Sci. Technol. 20 (1985) 185-203.

[28] Cuksey S.D.Q., Elston P.D., Bhaskar G.V., Vautier B.A., Lee S.K., Production of milk protein ingredient with high protein content, Patent WO2005/013710A1, 2005.

[29] Czulak J., Process for recovering the whey proteins, the application thereof to cheesemaking and the resulting cheeses, Patent US4518616, 1985.

[30] Dannenberg F., Kessler H.-G., Application of reaction kinetics to the denaturation of whey proteins in heated milk, Milchwissenschaft 43 (1988) 3-7.

[31] Dannenberg F., Kessler H.-G., Reaction kinetics of the denaturation of whey proteins in milk, J. Food Sci. 53 (1988) 259-263.

[32] Dannenberg F., Kessler H.-G., Effect of denaturation of $\beta$-lactoglobulin on texture properties of set-style nonfat yoghurt. 1. Syneresis, Milchwissenschaft 43 (1988) 632-635.

[33] Dannenberg F., Kessler H.-G., Effect of denaturation of $\beta$-lactoglobulin on texture properties of set-style nonfat yoghurt. 2. Firmness and flow properties, Milchwissenschaft 43 (1988) 700-705.

[34] Davis J.P., Foegeding E.A., Foaming and interfacial properties of polymerised whey protein isolate, J. Food Sci. 69 (2004) 404410.

[35] De la Fuente M.A., Singh H., Hemar Y., Recent advances in the characterisation of heat-induced aggregates and intermediates of whey proteins, Trends Food Sci. Technol. 13 (2002) 262-274.

[36] De Roos A.L., Geurts T.J., Walstra P., The association of chymosin with artificial casein micelles, Int. Dairy J. 10 (2000) 225-232.

[37] Delespaul G., Remars J., Procédé de fabrication de fromages à partir de lait chauffé à des températures élevées ou de lait en poudre recombiné ou reconstitué, et nouveaux produits ainsi obtenus, Patent FR2465422, 1981.

[38] Ernstrom C.A., Sutherland B.J., Jameson G.W., Cheese base for processing. A high yield product from whole milk by ultrafiltration, J. Dairy Sci. 63 (1980) 228-234.

[39] Famelart M.-H., Environnement minéral et propriétés de gélification des caséines, in: Gaucheron F. (Ed.), Minéraux et produits laitiers, Lavoisier, Paris, France, 2004, pp. 585-617.

[40] Fang C.-S., Snook R., Proteinaceous fat substitute, Patent WO91/17665, 1991.

[41] FAO/WHO, General standard for cheese, Codex Alimentarius, STAN-A-6, (1978, revised in 1999, amended in 2003). 
[42] FAO/WHO, Codex standard for whey cheese, Codex Alimentarius, STAN-A-7, (1978, revised in 1999).

[43] FAO/WHO, General principles for the addition of essential nutrients to foods, Codex Alimentarius, CAC/GL-09 (1987, amended in 1989, 1991).

[44] FAO/WHO, General standard for food additives, Codex Alimentarius, CAC/STAN-192 (1995, revised in 2004).

[45] FAO/WHO, Report of the fifth session of the Codex committee on milk and milk products, Codex Alimentarius, ALINORM 03/11 (2002).

[46] Farkye N.Y., Prasad B.B., California cooking cheese, Patent US5573806, 1996.

[47] Feldstein F.J., Westhoff D.C., The influence of heat treatment of milk on starter activity: what about UHT ? Cultur. Dairy Prod. J. 14 (1979) 11-15.

[48] Fenelon M.A., Guinee T.P., The compositional, textural and maturation characteristics of reduced-fat Cheddar made from milk containing added Dairy-Lo, Milchwissenschaft 52 (1997) 385-389.

[49] Ferron-Baumy C., Maubois J.-L., Garric G., Quiblier J.-P., Coagulation présure du lait et des rétentats d'ultrafiltration. Effets de divers traitements thermiques, Lait 71 (1991) 423434.

[50] Ferron-Baumy C., Mollé D., Garric G., Maubois J.-L., Characterization of caseinomacropeptides released from renneted raw and UHT treated milks, Lait 72 (1992) 165-173.

[51] Garnot P., Mollé D., Piot M., Influence of pH, type of enzyme and ultrafiltration on the retention of milk clotting enzymes in Camembert cheese, Lait 54 (1987) 315-320.

[52] Genvrain S.A., Amélioration à l'extraction des protéines du lactosérum, Patent FR1536183, 1968.

[53] Genvrain S.A., Procédé pour extraire de façon continue du lactosérum les protéines qu'il contient et produit obtenu, Patent FR1555757, 1969.

[54] Ghosh B.C., Steffl A., Hinrichs J., Kessler H.-G., Effect of heat-treatment and homogenization of milk on Camembert-type cheese, Egypt. J. Dairy Sci. 27 (1999) 331-343.

[55] Goudédranche H., Ducruet P., Vachot J.-C., Pannetier R., Maubois J.-L., Utilisation du lysozyme en tant qu'agent régulateur de l'affinage en fromagerie MMV, Lait 66 (1986) 189-206.

[56] Goudédranche H., Camier B., Gassi J.-Y., Schuck P., Procédés de transformation fro- magère, Partie 3, in: Techniques de l'ingénieur, F6-307 (2002) 1-11, appendix F6-308, pp. 1-4.

[57] Grufferty M.B., Mulvihill D.M., Proteins recovered from milks heated at alkaline $\mathrm{pH}$ values, J. Soc. Dairy Technol. 40 (1987) 8285 .

[58] Guinee T.P., Pudja P.D., Reville W.J., Harrington D., Mulholland E.O., Cotter M., Cogan T.M., Composition, microstructure and maturation of semi-hard cheeses from high protein ultrafiltered milk retentates with different levels of denatured whey protein, Int. Dairy J. 5 (1995) 543-568.

[59] Guinee T.P., O’Callaghan D.J., Pudja P.D., O'Brien N., Rennet coagulation properties of retentates obtained by ultrafiltration of skim milks heated to different temperatures, Int. Dairy J. 6 (1996) 581-596.

[60] Guinee T.P., Gorry C.B., O’Callaghan D.J., O’Kennedy B.T., O’Brien N., Fenelon M.A., The effects of composition and some processing treatments on the rennet coagulation properties of milk, Int. J. Dairy Technol. 50 (1997) 99-106.

[61] Guillaume C., Jiménez L., Cuq J.-L., Marchesseau S., An original pH-reversible treatment of milk to improve rennet gelation, Int. Dairy J. 14 (2004) 305-311.

[62] Guyomarc'h F., Law A.J.R., Dalgleish D.G., Formation of soluble and micelle-bound protein aggregates in heated milk, J. Agric. Food Chem. 51 (2003) 4652-4660.

[63] Hansen K., Stability of plasmin and plasminogen in UF retentate and cheese, in: Posters and brief communications of the XXIIIth International Dairy Congress, Oct 8-12th, 1990, Montreal, Canada, 3 (1991) 272.

[64] Hassan F.A.M., Abd El-Gawad M.A.M., Manufacture of Mozzarella cheese supplemented with different protein concentrates, Egypt. J. Dairy Sci. 28 (2000) 37-48.

[65] Hinrichs J., Incorporation of whey proteins in cheese, Int. Dairy J. 11 (2001) 495-503.

[66] Hoffmann M.A.M., Van Mil P.J.J.M., Heatinduced aggregation of beta-lactoglobulin: role of the free thiol group and disulfide bonds, J. Agric. Food Chem. 45 (1997) 29422948.

[67] Hoffmann M.A.M., Van Mil P.J.J.M., Heatinduced aggregation of beta-lactoglobulin as a function of pH, J. Agric. Food Chem. 47 (1999) 1898-1905.

[68] Hoffmann M.A.M., Sala G., Olieman C., De Kruif K.G., Molecular mass distributions of heat-induced beta-lactoglobulin aggregates, J. Agric. Food Chem. 45 (1997) 2949-2957. 
[69] Holmes D.G., Duersch J.W., Ernstrom C.A., Distribution of milk clotting enzymes between curd and whey and their survival during Cheddar cheese making, J. Dairy Sci. 60 (1977) 862-869.

[70] Huss M., Spiegel T., Preparation of an aggregate whey protein product and its use, Patent WO00/48473, 2000.

[71] Imafidon G.I., Farkye N.Y., Rennet coagulability of high-heat treated milk influenced by time of $\mathrm{pH}$ adjustment, J. Food Sci. 58 (1993) 1300-1302.

[72] Imafidon G.I., Farkye N.Y., Composition of Cheddar cheese made from high-heat treated milk, in: Emmons D.B. (Ed.), Cheese yield and factors affecting its control, IDF Seminar in Cork, International Dairy Federation, Bruxelles, Belgium, Special Issue 9402, 1994, pp. 433-438.

[73] Imafidon G.I., Farkye N.Y., Tong P.S., Effect of high-heat treatment and different acidulants on the physicochemical properties of rennet treated milk, J. Dairy Sci. 75 Suppl. 1 (1992) 120.

[74] Jameson G.W., Lelièvre J., Effects of whey proteins on cheese characteristics, Bull. IDF 313 (1996) 3-8.

[75] Jameson G.W., Sutherland B.J., Process for producing cheese containing substantially all the casein and whey protein in milk, Patent US5356639, 1994.

[76] Jean K., Renan M., Famelart M.-H., Guyomarc'h F., Structure and surface properties of the serum heat-induced protein aggregates isolated from heated skim milk, Int. Dairy J. 16 (2006) 303-315.

[77] Kelly A.L., The influence of heat-treatment of milk on proteolysis in Cheddar cheese during ripening, Milchwissenschaft 54 (1999) 682-685.

[78] Kelly A.L., Foley J., Proteolysis and storage stability of UHT as influenced by milk plasmin activity, plasmin/ $\beta$-lactoglobulin complexation, plasminogen activation and somatic cell count, Int. Dairy J. 7 (1997) 411-420.

[79] Kinsella J.E., Whitehead D.M., Proteins in whey: chemical, physical and functional properties, Adv. Food Nutr. Res. 33 (1989) 343-438.

[80] Klantschitsch T., Bachmann H.-P., Puhan Z., Influence of milk treatment and ripening conditions on quality of Raclette cheese, Lait 80 (2000) 51-67.

[81] Korolczuk J., Mahaut M., Consistency of acid fresh cheese: role of the whey proteins, Milchwissenschaft 46 (1991) 153-156.

[82] Korolczuk J., Mahaut M., Effect of whey proteins and heat treatment of milk on the con- sistency of UF fresh cheese, Milchwissenschaft 46 (1991) 435-437.

[83] Krause I., Bockhardt A., Klostermeyer H., Characterization of cheese ripening by free amino acids and biogenic amines and influence of bactofugation and heat-treatment of milk, Lait 77 (1997) 101-108.

[84] Kuipers A., Schröder K., Method of preparing a protein-enriched unripened cheese composition, Patent DE2503840, 1976.

[85] Law A.J.R, Leaver J., Effect of $\mathrm{pH}$ on the thermal denaturation of whey proteins in milk, J. Agric. Food Chem. 48 (2000) 672-679.

[86] Law A.J.R., Banks J.M., Horne D.S., Leaver J., West I.G., Denaturation of the whey proteins in heated milk and their incorporation into Cheddar cheese, Milchwissenschaft 49 (1994) 63-67.

[87] Lawrence R.C., Lelièvre J., Whey protein in cheese, in: Proceedings of the XXIIIth International Dairy Congress, Vol. 3, Oct 8-12, 1990, Montreal, Canada, 3, pp. 1880-1888.

[88] Le Graët Y., Gaucheron F., pH-induced solubilization of minerals from casein micelles: influence of casein concentration and ionic strength, J. Dairy Res. 66 (1999) 215-224.

[89] Leaver J., Law A.J.R., Horne D.S., Banks J.M., Influence of heating regime and $\mathrm{pH}$ on the primary phase of renneting of whole milk, Int. Dairy J. 5 (1995) 129-140.

[90] Lelièvre J., Creamer L.K., Tate K.L., Inhibition of calf vell and microbial rennet action by whey protein concentrate, Milchwissenschaft 45 (1990) 71-75.

[91] Léonil J., Bos C., Maubois J.-L., Tomé D., Le lait et ses constituants : biodisponibilité et valeur nutritionnelle, protéines (Partie II), in: Debry G. (Ed.), Lait, nutrition et santé, Lavoisier Tec \& Doc, Paris, France, 2001, pp. 45-83.

[92] Lieske B., Influence of preliminary treatments on structural properties of casein micelles affecting the rennetability, Lait 77 (1997) 201-209.

[93] Lo C.G., Bastian E.D., Incorporation of native and denatured whey proteins into cheese curd for manufacture of reduced fat, Havarti-type cheese, J. Dairy Sci. 81 (1998) 16-24.

[94] Lowe E.K., Anema S.G., Lee S.K., Process for producing yoghurt with controlled texture and consistency, Patent WO016015, 2005.

[95] Lucey J.A., Effect of heat treatment on the rennet coagulability of milk, in: Fox P.F. (Ed.), Heat-induced changes in milk, 2nd edn., International Dairy Federation, Bruxelles, Belgium, Special Issue 9501, 1995, pp. 171-187. 
[96] Lucey J.A., Gorry C.B., Effect of Simplesse 100 on the manufacture of low fat Cheddar cheese, in: Emmons D.B. (Ed.), Cheese yield and factors affecting its control, IDF Seminar in Cork, International Dairy Federation, Bruxelles, Belgium, Special Issue 9402, 1994, pp. 439-447.

[97] Lucey J.A., Gorry C.B., Fox P.F., Acid-base buffering properties of heated milk, Milchwissenschaft 48 (1993) 438-441.

[98] Lucey J.A., Gorry C., O'Kennedy B.T., Kaláb M., Tan-Kinita R., Fox P.F., Effect of acidification and neutralization of milk on some physico-chemical properties of casein micelles, Int. Dairy J. 6 (1996) 257-272.

[99] Lucey J.A., Tamehana M., Singh H., Munro P.A., Effect of heat treatment on the physical properties of milk gels made with both rennet and acid, Int. Dairy J. 11 (2001) 559-565.

[100] Madsen J.S., Qvist K.B., The effect of added proteolytic enzymes on meltability of Mozzarella cheese manufactured by ultrafiltration, Lait 78 (1998) 259-272.

[101] Mahaut M., Korolczuk J., Effect of whey protein addition and heat treatment of milk on the viscosity of UF fresh cheese, Milchwissenschaft 47 (1992) 157-159.

[102] Marshall R.J., Increasing cheese yields by high heat-treatment of milk, J. Dairy Res. 53 (1986) 313-322.

[103] Maubois J.-L., Mocquot G., Vassal L., Procédé de traitement du lait et de sous-produits laitiers, Patent FR2052121, 1971.

[104] Maubois J.-L., Fauquant J., Brulé G., Procédé de traitement de matières contenant des protéines, telles que le lait, Patent FR2292435, 1977.

[105] Maubois J.-L., Fauquant J., Famelart M.-H., Caussin F., Milk microfiltrate, a convenient starting material for fractionation of whey proteins and derivatives, in: Proceedings of the 3rd International Whey Conference, Sept. 12-14, 2001, Munich, Germany, pp. 59-72.

[106] McMahon D.J., Yousif B.H., Kaláb M., Effect of whey protein denaturation on structure of casein micelles and their rennetability after ultra-high temperature processing of milk with or without ultrafiltration, Int. Dairy J. 3 (1993) 239-256.

[107] Mead D., Roupas P., Effect of incorporation of denatured whey proteins on chemical composition and functionality of pizza cheese, Aust. J. Dairy Technol. 56 (2001) 19-23.

[108] Ménard O., Camier B., Guyomarc'h F., Effect of heat treatment at alkaline $\mathrm{pH}$ on the rennet coagulation properties of skim milk, Lait 85 (2005) 515-526.

[109] Mietton B., La standardisation des laits de fromagerie, Proceedings of the XXIIIth International Dairy Congress, Oct $8-12$, 1990, Montreal, Canada, 3, pp. 1838-1865.

[110] Mignot B.M., Tracard H., Procédé d'incorporation aux fromages, sous forme colloïdale, des lactoprotéines thermocoagulables du lait, Patent FR2301180, 1976.

[111] Mistry V.V., Kasperson K.M., Influence of salt on the quality of reduced fat Cheddar cheese, J. Dairy Sci. 81 (1998) 1214-1221.

[112] Mistry V.V., Maubois J.-L., Application of membrane separation technology to cheese production, in: Fox P.F. (Ed.), Cheese: chemistry, physics and microbiology. Volume 1: general aspects, 2 nd edn., Chapman \& Hall, London, UK, 1993, pp. 493-522.

[113] Monahan F.J., German J.B., Kinsella J.E., Effect of $\mathrm{pH}$ and temperature on protein unfolding and thiol/disulfide interchange reactions during heat-induced gelation of whey proteins, J. Agric. Food Chem. 43 (1995) 46-52.

[114] Morrissey P.A., Rennet clotting properties of heated milk systems, J. Dept. Agric. Fish. 68 (1973) 10-15.

[115] Nelson B.K., Barbano D.M., A microfiltration process to maximize removal of serum proteins from skim milk before cheese making, J. Dairy Sci. 88 (2005) 1891-1900.

[116] Oldfield D.J., Singh H., Taylor M.W., Pearce K.N., Kinetics of denaturation and aggregation of whey proteins in skim milk heated in an ultra-high temperature (UHT) pilot plant, Int. Dairy J. 8 (1998) 311-318.

[117] Oldfield D.J., Singh H., Taylor M.W., Pearce K.N., Heat-induced interactions of $\beta$ lactoglobulin and $\alpha$-lactalbumin with the casein micelle in $\mathrm{pH}$-adjusted skim milk, Int. Dairy J. 10 (2000) 509-518.

[118] Ott H., Dolle E., Bücker H., Verfahren und Vorrichtung zur kontinuierlichen Gewinnung von Quark aus Magermilch, Patent DE2636882, 1978.

[119] Pannetier J., Procédé pour la récupération des protéines de lactosérum, installation pour sa mise en œuvre et applications, notamment à la production fromagère, Patent FR2529759, 1984

[120] Park S.Y., Nakamura K., Niki R., Effects of $\beta$-lactogobulin on the rheological properties of casein micelle rennet gels, J. Dairy Sci. 79 (1996) 2137-2145

[121] Pearse M.J., Linklater P.M., Hall R.J., Mc Kinlay A., Effect of heat-induced interaction 
between $\beta$-lactoglobulin and $\kappa$-casein on syneresis, J. Dairy Res. 52 (1985) 159-165.

[122] Pierre A., Brulé G., Fauquant J., Piot M., Influence des traitements thermiques sur les propriétés physico-chimiques des rétentats obtenus par ultrafiltration de lait de vache et de lait de chèvre. I. Dénaturation des protéines solubles, Lait 57 (1977) 646-662.

[123] Plock J., Spiegel T., Kessler H.-G., Influence of the dry matter on the denaturation kinetics of whey proteins in concentrated sweet whey, Milchwissenschaft 53 (1998) 327-331.

[124] Plock J., Spiegel T., Kessler H.-G., Influence of the lactose concentration on the denaturation kinetics of whey proteins in concentrated sweet whey, Milchwissenschaft 53 (1998) 389-393.

[125] Punidadas P., Tung M.A., Feirtag J., Potential use of homogenized whey protein dispersions and process modification for the manufacture of low fat and reduced fat Cheddar type cheeses, Int. J. Dairy Technol. 53 (2000) 45-50.

[126] Quiblier J.-P., Ferron-Baumy C., Garric G., Maubois J.-L., Procédé de traitement des laits permettant au moins de conserver leur aptitude fromagère, Patent FR2681218, 1993.

[127] Ramet J.-P., Technologie comparée des différents types de caillés, in: Eck A., Gillis J.-C. (Eds.), Le fromage, 3rd edn., Lavoisier, Paris, France, 1997, pp. 334-364.

[128] Renan M., Mekmene O., Famelart M.-H., Guyomarc'h F., Delest-Arnoult V., Pâquet D., Brulé G., pH-dependent behaviour of soluble protein aggregates formed during heat-treatment of milk at $\mathrm{pH} 6.5$ or 7.2 , J. Dairy Res. (2006) in press.

[129] Rynne N.M., Beresford T.P., Kelly A.L., Guinee T.P., Effect of milk pasteurisation temperature an in situ whey protein denaturation on the composition, texture and heatinduced functionality of half-fat Cheddar cheese, Int. Dairy J. 14 (2004) 989-1001.

[130] Sanchelima J.A., Process for enhancing the incorporation of whey proteins in the cheese curd, Patent US6015579, 2000.

[131] Santoro M., Faccia M., Degradation of the protein fraction in a cheese fortified with whey proteins, Neth. Milk Dairy J. 50 (1996) 61-68.

[132] Schafer H.W., Olson N.F., Characteristics of Mozzarella cheese made by direct acidification from ultra-high-temperature processed milk, J. Dairy Sci. 58 (1975) 494-501.

[133] Schreiber R., Heat-induced modifications in casein dispersions affecting their rennetability, Int. Dairy J. 11 (2001) 553-558.
[134] Schreiber R., Hinrichs J., Rennet coagulation of heated milk concentrates, Lait 80 (2000) 33-42.

[135] Scott R., Recipes for cheese-making, in: Scott R. (Ed.), Cheese-making practice, Applied Science Publishers Ltd, London, UK, 1981, pp. 236-273.

[136] Serpelloni M., Procédé pour conférer des aptitudes fromagères à des laits surchauffés, en vue de la fabrication de fromages emprésurés, Patent FR2632493, 1989.

[137] Shammet K.M., Mc Mahon D.J., Ernstrom C.A., Effect of acidification and heat treatment on the quality of white soft cheese from ultrafiltered whole milk retentate, Milchwissenschaft 47 (1992) 553-557.

[138] Sharma S.K., Hill A.R., Goff H.D., The effect of heat treatment of ultrafiltered milk on its coagulation properties, Milchwissenschaft 45 (1990) 432-435.

[139] Singh H., Creamer L.K., Aggregation and dissociation of milk protein complexes in heated reconstituted concentrated skim milk, J. Food Sci. 56 (1991) 238-246.

[140] Singh H., Fox P.F., Heat stability of milk: further studies on the $\mathrm{pH}$-dependent dissociation of micellar kappa-casein, J. Dairy Res. 53 (1986) 237-248.

[141] Singh H., Fox P.F., Heat stability of milk: role of beta-lactoglobulin in the $\mathrm{pH}$-dependent dissociation of micellar kappa-casein, J. Dairy Res. 54 (1987) 509-521.

[142] Singh H., Waungana A., Influence of heat treatment of milk on cheese-making properties, Int. Dairy J. 11 (2001) 543-551.

[143] Singh H., Shalabi S.I., Fox P.F., Flynn A., Barry A., Rennet coagulation of heated milk: influence of $\mathrm{pH}$ adjustment before or after heating, J. Dairy Res. 55 (1988) 205215.

[144] Smits P., van Brouwershaven J.H., Heatinduced association of $\beta$-lactoglobulin and casein micelles, J. Dairy Res. 47 (1980) 313-325.

[145] Soeda T., Cheese whey protein having improved texture, process for producing the same, and use thereof, Patent US2001/ 0053398A1, 2001.

[146] Somers J.M., Kelly A.L., Contribution of plasmin to primary proteolysis during ripening of cheese: effect of milk heat treatment and cheese cooking temperature, Lait 82 (2002) 181-191.

[147] Spiegel T., Whey protein aggregation under shear conditions - effects of lactose and heating temperature on aggregate size and structure, Int. J. Food Sci. Technol. 34 (1999) 523-531. 
[148] Spiegel T., Huss M., Whey protein aggregation under shear conditions - effects of $\mathrm{pH}-$ value and removal of calcium, Int. J. Food Sci. Technol. 37 (2002) 559-568.

[149] Steffl A., Hafenmair M., Hechler A., Hinrichs $\mathrm{J}$. Influence of whey protein particles on the renneting properties of milk, Milchwissenschaft, 54 (1999) 510-513.

[150] Steffl A., Schreiber R., Hafenmair M., Kessler H.-G., Influence of whey protein aggregates on the renneting properties of milk, Int. Dairy J. 9 (1999) 403-404.

[151] Sueyasu R., Ueda K., Sagara K., Processes for the production of a cheese curd and cheese containing whey protein, Patent US5334398, 1994.

[152] Ustunol Z., Brown J., Effect of heat treatment and post-treatment holding time on rennet clotting of milk, J. Dairy Sci. 68 (1985) 526-530.

[153] Van Dijk H.J.M., The properties of casein micelles. 4. The effect of the addition of $\mathrm{NaCl}, \mathrm{MgCl} 2$ or $\mathrm{NaOH}$ on the partition of $\mathrm{Ca}, \mathrm{Mg}$ and PO4 in cow's milk, Neth. Milk Dairy J. 45 (1991) 241-251.

[154] Van Hooydonk A.C.M., De Koster P.G., Boerrigter I.J., The renneting properties of heated milk, Neth. Milk Dairy J. 41 (1987) 3-18.

[155] Vardhanabhuti B., Foegeding E.A., Mc Guffey M.K., Daubert C.R., Swaisgood H.E., Gelation properties of dispersions containing polymerised and native whey protein isolate, Food Hydrocolloids 15 (2001) 165175.

[156] Vasbinder A.J., De Kruif C.G., Caseinwhey protein interactions in heated milk: the influence of pH, Int. Dairy J. 13 (2003) 669677.

[157] Vasbinder A.J., Alting A.C., de Kruif K.G., Quantification of heat-induced casein-whey protein interactions in milk and its relation to gelation kinetics, Colloids Surf. B Biointerf. 31 (2003) 115-123.

[158] Vasbinder A.J., Rollema H.S., De Kruif C.G., Impaired rennetability of heated milk; study of enzymatic hydrolysis and gelation kinetics, J. Dairy Sci. 86 (2003) 1548-1555.
[159] Vassal L., Gripon J.-C., L'amertume des fromages à pâte molle de type Camembert : rôle de la présure et de Penicillium caseicolum, moyens de la contrôler, Lait 64 (1984) 397-417.

[160] Verheul M., Roefs S.P.F.M., De Kruif C.G. Gelation of whey proteins, Ind. Prot. 7 (1999) 19-20.

[161] Walker Y., Le Centriwhey, procédé permettant d'augmenter les rendements fromagers, in: Proceedings of the XVIIIth International Dairy Congress, Oct 12-16, 1970, Sydney, Australia, p. 334

[162] Walstra P., Jenness R., Salts, in: Walstra P., Jenness R. (Eds.), Dairy Chemistry and Physics, John Wiley and Sons, New York, USA, 1984, pp. 42-57.

[163] Wanatabe K., Klostemeyer H., Heat-induced changes in sulphydryl and disulphide levels of beta-lactoglobulin A and the formation of polymers, J. Dairy Res. 43 (1976) 411-418.

[164] Waungana A., Singh H., Bennett R.J., Influence of denaturation and aggregation of $\beta$-lactoglobulin on rennet coagulation properties of skim milk and ultrafiltered milk, Food Res. Int. 29 (1996) 715-721.

[165] Waungana A., Singh H., Bennett R.J., Rennet coagulation properties of skim milk concentrated by ultrafiltration: effects of heattreatment and $\mathrm{pH}$ adjustment, Food Res. Int. 31 (1998) 645-651.

[166] Yousif B.H., Mc Mahon D.J., Savello P.A., Brown R.J., Kaláb M., Effects of heat treatment of concentrated milk on its rennet coagulation time, gel microstructure and whey protein denaturation, J. Dairy Sci. 73 Suppl. 1 (1990) 105.

[167]Zhu H., Damodaran S., Heat-induced conformational changes in whey protein isolate and its relation to foaming properties, J. Agric. Food Chem. 42 (1994) 846-855.

[168] Zoon P., Incorporation of whey proteins into Dutch-type cheese, in: Emmons D.B. (Ed.), Cheese yield and factors affecting its control, IDF Seminar in Cork, International Dairy Federation, Bruxelles, Belgium, Special Issue 9402, 1994, pp. 402-408. 